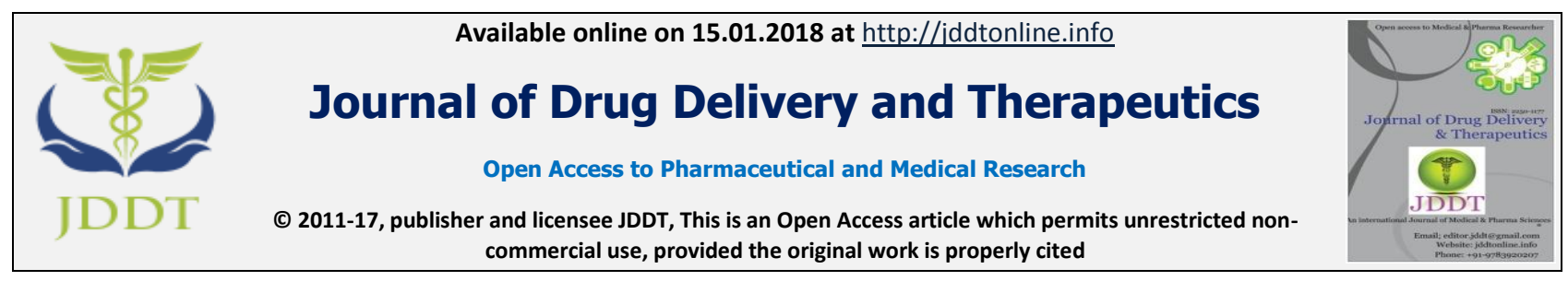

Open 8 Access

Research Article

\title{
PREFORMULATION STUDIES OF DILTIAZEM HYDROCHLORIDE FROM TABLETED MICROSPHERES
}

\author{
Manish Kumar Gupta ${ }^{1 *}$, Surendra Kumar Swarnkar ${ }^{2}$ \\ ${ }^{1}$ Professor and Principal, Jaipur College of Pharmacy, Jaipur, Rajasthan, India \\ ${ }^{2}$ Assistant Professor, LBS College of Pharmacy, Jaipur, Rajasthan, India
}

\begin{abstract}
Microspheres are solid, spherical particles of protein or polymer-based matrix which comprised of a fairly homogeneous mixture of polymer and active agents.It undergoes considerable presystemic metabolism (45-55\%) which results in reduced bioavailability. Diltiazem hydrochloride was scanned in the Methanol, acid buffer, $\mathrm{pH}$ 1.2and phosphate buffer, $\mathrm{pH} 7.2 .10 \mathrm{mg}$ of drug was dissolved in methanol in $100 \mathrm{ml}$ in volumetric flask, and volume was made to $100 \mathrm{ml}$ with same solvent. This stock solution was further diluted to get concentration of $10 \mathrm{mcg} / \mathrm{ml}$. This solution was scanned in UV-spectrophotometer and characteristic peak was observed at $239 \mathrm{~nm}$ for methanol, $237 \mathrm{~nm}$ for acid buffer, $\mathrm{pH} 1.2$ and phosphate buffer, pH 7.2. Standard curve of Diltiazem hydrochloride was plotted in Methanol, acid buffer $(\mathrm{pH}$ 1.2) and phosphate buffer ( $\mathrm{pH}$ 7.2). The critical values for regression coefficient in each plot were less than 0.001 (i.e., $\mathrm{P}<0.001$ ). That indicates that there was a high linear correlationbetween concentration of drug with absorbance.
\end{abstract}

Keywords: Diltiazem hydrochloride, regression coefficient, bioavailability, Microspheres.

Article Info: Received 11 Nov, 2017; Review Completed 08 Jan, 2018; Accepted 09 Jan, 2018; Available online 15 Jan, 2018

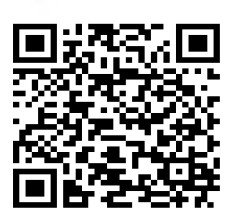

Cite this article as:

Gupta MK, Swarnkar SK, Preformulation studies of diltiazem hydrochloride from tableted microspheres, Journal of Drug Delivery and Therapeutics. 2018; 8(1):64-69

DOI: http://dx.doi.org/10.22270/jddt.v8i1.1552

*Address for Correspondence

Gupta MK, Swarnkar SK, Preformulation studies of diltiazem hydrochloride from tableted microspheres

\section{INTRODUCTION}

Oral delivery of drugs is by far the most preferable route of drug delivery due to the ease of administration, patient compliance and flexibility in formulation, etc. The frequency of administration or the dosing interval of any drug depends upon its half-life or mean residence time (MRT) and its therapeutic index. In most cases, the dosing interval is much shorter than the half-life of the drug resulting in a number of limitations. These limitations can overcome by formulating into ModifiedRelease dosage forms. Modified-release products provide either delayed-release or extended-release of the drug. ${ }^{2}$

There are three types of controlled drug delivery systems available: ${ }^{3}$
- Passive preprogrammed, in which the release rate is predetermined and is irresponsive to the external biological environment.

- Active preprogrammed, whose release rate can be altered by a source external to the body (include most metered insulin pumps).

- Active, self-programmed, modulate release rate of the drug in response to information, registered by a sensor, on the changing biological environment, such as blood sugar level in diabetes.

Biological factors influencing design and performance of sustained / controlled release products $^{3}$

- Absorption

- Distribution 
- Metabolism

- Duration of Action

- Side effects

- Margin of safety

- Role of disease state

- Role of circadian rhythm

\section{Microspheres}

Microspheres are solid, spherical particles of protein or polymer based matrix which comprised of a fairly homogeneous mixture of polymer and active agents. Microspheres usually have diffusion controlled release profiles with a permanent release rate that is controlled kinetically by the particle size, whereas microcapsules usually have diffusion or dissolution controlled release profiles or both. Microcapsules expel their content by a single high burst as the shell breaks or slow releases. ${ }^{4,5}$,

\section{MATERIALS AND METHODS}

Drug profile: Diltiazem Hydrochloride

Diltiazem hydrochloride is a calcium channel blocker (benzothiazepine), widely used for the treatment of angina pectoris, arrhythmias and hypertension.

Table 1: Parameter of Drug profile

\begin{tabular}{|c|c|c|}
\hline Description & Properties & Given Data \\
\hline \multirow[t]{12}{*}{ Chemistry $^{7}$} & Chemical Structure & \\
\hline & Chemical Name & $\begin{array}{l}\text { (+)-cis-2,3,4,5-tetrahydro-5-(2-dimethylaminoethyl)-2- (4- } \\
\text { methoxyphenyl)-4-oxobenzo[b]thiazepin-3-yl acetatemonohydrochloride }\end{array}$ \\
\hline & Molecular Formula & $\mathrm{C}_{22} \mathrm{H}_{26} \mathrm{~N}_{2} \mathrm{O}_{4} \mathrm{~S} . \mathrm{HCl}$ \\
\hline & Molecular Weight & 450.98 \\
\hline & Description & White, crystalline powder or small crystals, Odorless and has a bitter taste \\
\hline & CAS Registry Number & $33286-22-5$ \\
\hline & Melting Point & $210^{\circ} \mathrm{C}\left[207.5^{\circ} \mathrm{C}-212^{\circ} \mathrm{C}\right]$ \\
\hline & Optical Rotation & $\begin{array}{l}\text { The optical rotation of a } 1 \%(\mathrm{w} / \mathrm{v}) \text { solution of diltiazemhydrochloride in } \\
\text { water at } 25^{\circ} \mathrm{C}\left(\left[\alpha_{\mathrm{D}}^{25}\right]\right) \text { is between }+100^{\circ} \text { and }+116^{\circ}\end{array}$ \\
\hline & Polymorphism & No polymorphs of diltiazem hydrochloride have been reported to date \\
\hline & $\mathrm{pH}$ & $\begin{array}{l}\mathrm{pH} \text { of saturated solution in water }=3.0 \\
\mathrm{pH} \text { of } 1.0 \%(\mathrm{w} / \mathrm{w}) \text { solution in water }=4.2\end{array}$ \\
\hline & $\mathrm{pKa}$ & $7.7+4$ \\
\hline & Stability $^{9}$ & $\begin{array}{l}\text { In } 1 \mathrm{~N} \text { hydrochloric acid at } 25^{\circ} \mathrm{C}, 59.5 \% \text { of the sample was degraded in } 24 \\
\text { hrs }\end{array}$ \\
\hline \multirow{16}{*}{$\begin{array}{l}\text { Pharmacoki } \\
\text { netics }\end{array}$} & Oral absorption & 90\% (Uniformly absorbed Throughout the GIT \\
\hline & Presystemic metabolism & $45-55 \%$ \\
\hline & Oral bioavailability & $38 \pm 11 \%$ \\
\hline & Plasma half life Range & $2-11 \mathrm{~h}$ \\
\hline & Mean (single dose) & $4.5 \mathrm{~h}(\leftrightarrow \mathrm{RD}$, Aged $)$ (does not change with multiple dosing) \\
\hline & Peak time & $4.0 \pm 0.4 \mathrm{~h}$ \\
\hline & Peak concentrations & $151 \pm 46 \mathrm{ng} / \mathrm{ml}($ Following a single $120 \mathrm{mg}$ oral dose $)$ \\
\hline & Volume of distribution & $3.3 \pm 1.2$ liter. $\mathrm{kg}^{-1}(\leftrightarrow$ Aged, $\downarrow \mathrm{RD})$ \\
\hline & Plasma protein binding & $80-90 \%$ \\
\hline & Clearance & $11.8 \pm 2.2(\leftrightarrow$ Aged, $\downarrow$ RD $)$ \\
\hline & Metabolism & Metabolized in the liver and at least six metabolites have been identified \\
\hline & Urinary Excretion & $<4 \%$ \\
\hline & $\begin{array}{l}\text { Concentration - effect } \\
\text { relationship }\end{array}$ & $\begin{array}{l}\text { The minimum therapeutic plasma concentration appears to be in the range } \\
\text { of } 50-120 \mathrm{ng} / \mathrm{ml}\end{array}$ \\
\hline & Therapeutic Uses & $\begin{array}{l}\text { Stable/ Unstable angina pectoris, MI, Coronary artery spasm, } \\
\text { Hypertension, Arrhythmias, Raynaud's phenomenon, Esophageal motility } \\
\text { disorders, Migraine, Primary pulmonary hypertension }\end{array}$ \\
\hline & Therapeutic dose & $\begin{array}{l}30 \text { to } 60 \mathrm{mg} \text { (three to four times a day). } \\
\text { Loading dose }=0.25-0.35 \mathrm{mg} / \mathrm{kg} \text { over } 10 \mathrm{~min} \text {. } \\
\text { Maintenance dose }=5-15 \mathrm{mg} / \mathrm{h}\end{array}$ \\
\hline & Mechanism of Action: ${ }^{10}$ & $\begin{array}{l}\text { Diltiazem is an inhibitor of calcium ion influx and causes a dose- } \\
\text { dependent, inhibition of the transmembrane influx of calcium ions into }\end{array}$ \\
\hline
\end{tabular}




\begin{tabular}{|c|c|c|}
\hline & & $\begin{array}{l}\text { into muscle via the 'L' channel. Diltiazem block calcium channels in } \\
\text { cardiac cells at clinically used doses. }\end{array}$ \\
\hline $\begin{array}{l}\text { Pharmacod } \\
\text { ynamic } \\
\text { Parameters }\end{array}$ & & $\begin{array}{l}\text { Therapeutic Index }- \text { Wide }\left[\mathrm{LD}_{50} \text { in male ,female mice, male, female rats : }\right. \\
740,640,560,610 \mathrm{mg} / \mathrm{kg} \text { orally] } \\
\text { Plasma drug concentration response - Good }\end{array}$ \\
\hline \multirow[t]{2}{*}{$\begin{array}{l}\text { Physical } \\
\text { Property }\end{array}$} & $\begin{array}{l}\text { Solubility of Diltiazem- } \\
\mathrm{HCl} \text { in various solvents }\end{array}$ & $\begin{array}{l}\text { In Chloroform, Methanol and Water: Freely soluble } \\
\text { In Dehydrated alcohol: Sparingly soluble } \\
\text { In Benzene: Practically insoluble. In Ether: Insoluble }\end{array}$ \\
\hline & $\begin{array}{l}\text { Solubility of Diltiazem- } \\
\mathrm{HCl} \text { at Various } \mathrm{pH} \\
\text { Buffer }{ }^{13}(\mathrm{mg} / \mathrm{ml}) \pm \% \mathrm{RSD}\end{array}$ & $\begin{array}{l}\mathrm{HCl}(1.2): 658.83 \pm 4.40 \\
\text { Phosphate Buffer (5.0)597.51 } \pm 1.54 \\
\text { Phosphate Buffer (7.4)593.20 } \pm 3.67 \\
\text { Phosphate Buffer (8.0)511.06 } \pm 3.94\end{array}$ \\
\hline Category & & Calcium channel blocker, Antianginal, Antihypertensive \\
\hline
\end{tabular}

\section{Therapeutically Beneficial Parameters ${ }^{10}$}

The area under the plasma concentration curve (AUC) is substantially higher in chronic dosing, than after a single dose. Therefore, following a $90 \mathrm{mg}$ single dose, the area was $505 \mu \mathrm{g} \mathrm{liter}{ }^{-1} \cdot \mathrm{h}^{-1}$, but when the same dose was given every 6 hour for 4 days, the AUC increased to $1216 \mu \mathrm{g}$ liter $^{-1} \cdot \mathrm{h}^{-1}$

- Diltiazem hydrochloride is approved for clinical use in the United States.

- It is not available in combination preparations.

Preformulation Studies

\section{Scanning of the drug (Diltiazem hydrochloride)}

Diltiazem hydrochloride was scanned in the following solvent and buffers -

i) Methanol

ii) Acid Buffer, $\mathrm{pH} 1.2$

iii) Phosphate Buffer, $\mathrm{pH} 7.2$

i) Scanning of the drug in solvent methanol
$10 \mathrm{mg}$ of drug was dissolved in methanol in $100 \mathrm{ml}$ in volumetric flask, and volume was made to $100 \mathrm{ml}$ with same solvent. This stock solution was further diluted to get concentration of $10 \mathrm{mcg} / \mathrm{ml}$. This solution was scanned in UV-spectrophotometer and characteristic peak was observed at $239 \mathrm{~nm}$.

\section{ii) Scanning of the drug in acid buffer, pH 1.2}

$10 \mathrm{mg}$ of drug was dissolved in acid buffer $\mathrm{pH}, 1.2$ in a $100 \mathrm{ml}$ volumetric flask, and volume was made to 100 $\mathrm{ml}$ with same solvent. This stock solution was further diluted by acid buffer to get concentration of $10 \mathrm{mcg} / \mathrm{ml}$. This final solution was scanned in UVspectrophotometer. The characteristic peak was observed at $237 \mathrm{~nm}$.

\section{iii) Scanning of drug in phosphate buffer, $\mathrm{pH} 7.2$}

$10 \mathrm{mg}$ of drug was dissolved in phosphate buffer $\mathrm{pH}, 7.2$ in a $100 \mathrm{ml}$ volumetric flask, and volume was made to $100 \mathrm{ml}$ with same solvent. This stock solution was further diluted by phosphate buffer to get concentration of $10 \mathrm{mcg} / \mathrm{ml}$. This final solution was scanned in UVspectrophotometer. The characteristic peak was observed at $237 \mathrm{~nm}$.

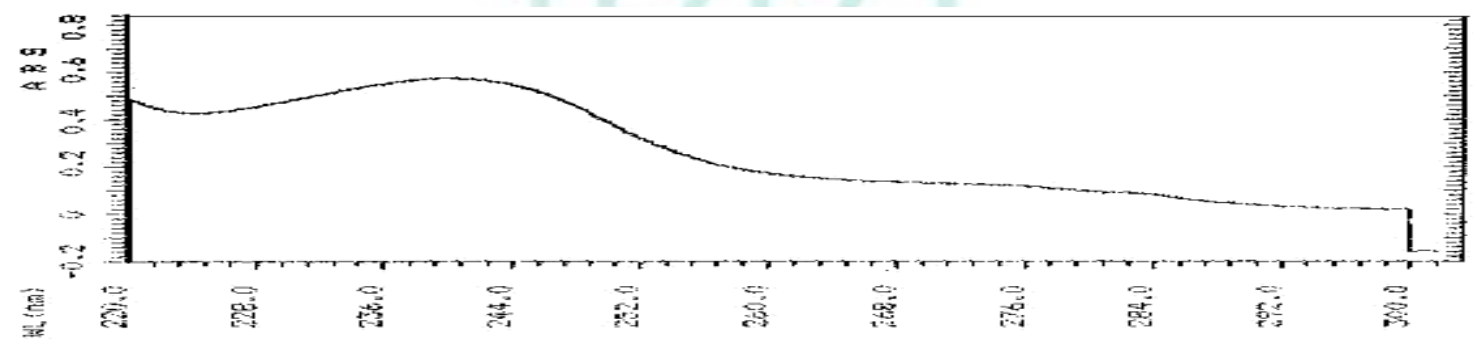

Figure 1: UV Spectrum of Diltiazem hydrochloride in solvent methanol)

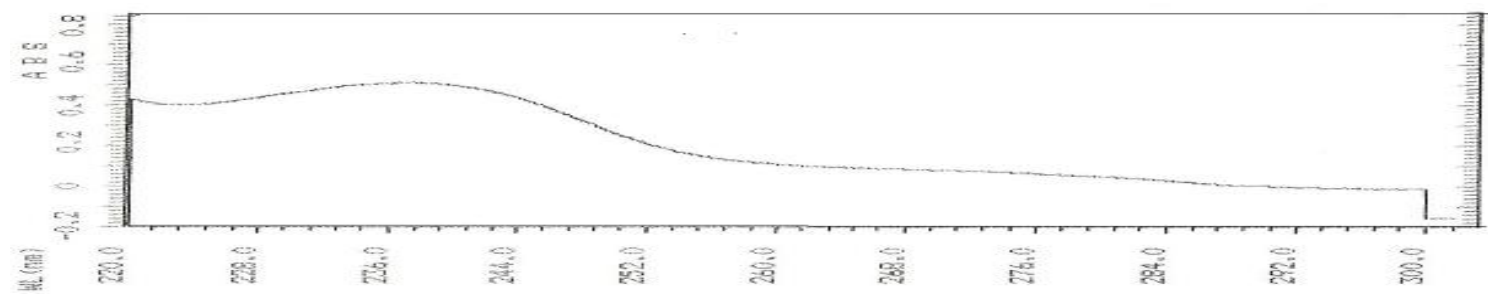

Figure 2: UV Spectrum of Diltiazem hydrochloride in acid buffer pH 1.2) 
Table 2: Summary of the scanning of Diltiazem hydrochloride in solvent methanol and buffers

\begin{tabular}{|c|c|c|c|c|c|c|c|}
\hline $\begin{array}{l}\text { S. } \\
\text { No. }\end{array}$ & $\begin{array}{l}\text { Amount of } \\
\text { Diltiazem } \\
\text { Hydrochloride } \\
(\mathrm{mg})\end{array}$ & $\begin{array}{l}\text { Solvent used to } \\
\text { make up } \\
\text { volume }\end{array}$ & $\begin{array}{l}\text { Final } \\
\text { volume } \\
(\mathrm{ml})\end{array}$ & $\begin{array}{l}\text { Concentration } \\
\text { of stock } \\
\text { solution } \\
(\mathrm{mcg} / \mathrm{ml})\end{array}$ & $\begin{array}{l}\text { Concentration } \\
\text { of scanning } \\
\text { solution } \\
(\mathrm{mcg} / \mathrm{ml})\end{array}$ & $\begin{array}{l}\text { Scanning } \\
\text { range }\end{array}$ & $\begin{array}{l}\text { Characteristic } \\
\text { peak, } \lambda_{\max }(\mathrm{nm})\end{array}$ \\
\hline 1 & 10 & Methanol & \multirow[b]{3}{*}{ 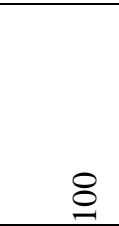 } & 100 & 10 & \multirow{3}{*}{ 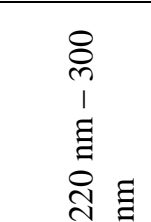 } & 239 \\
\hline 2 & 10 & $\begin{array}{l}\text { Acid Buffer, } \\
\text { pH } 1.2\end{array}$ & & 100 & 10 & & 237 \\
\hline 3 & 10 & $\begin{array}{l}\text { Phosphate } \\
\text { Buffer, pH } 7.2\end{array}$ & & 100 & 10 & & 237 \\
\hline
\end{tabular}

\section{RESULTS}

\section{Infrared Spectroscopy}

The IR spectrum of pure drug, Eudragit RL100,

Eudragit RS100, Eudragit RLPO, Eudragit RSPO,
Magnesium stearate, were recorded in potassium bromide using Shimadzu FTIR - 8400 S(CE). The range of scanning was $500 \mathrm{~cm}^{-1}-4000 \mathrm{~cm}^{-1}$.

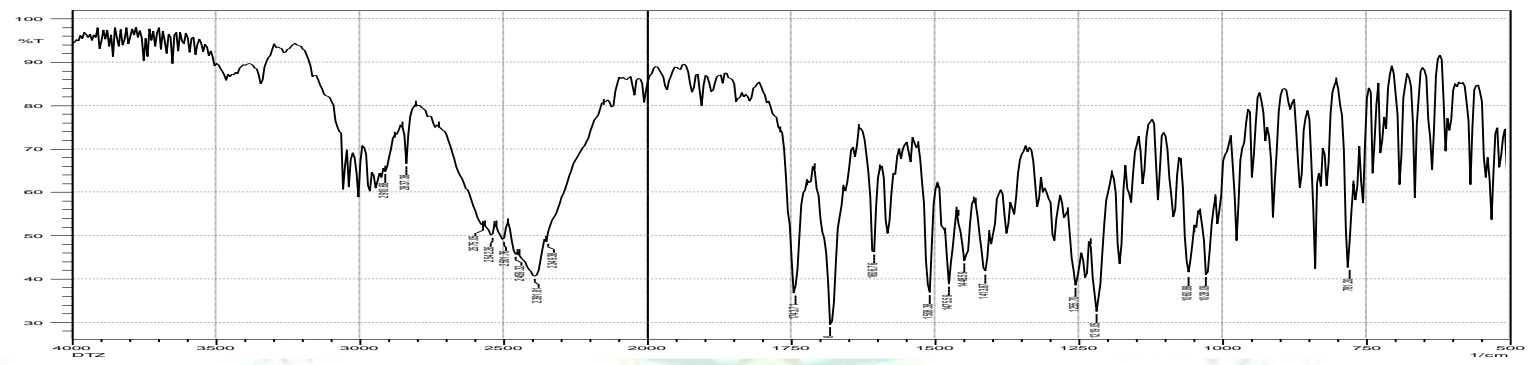

Figure 3: IR Spectrum of Diltiazemhydroccloride

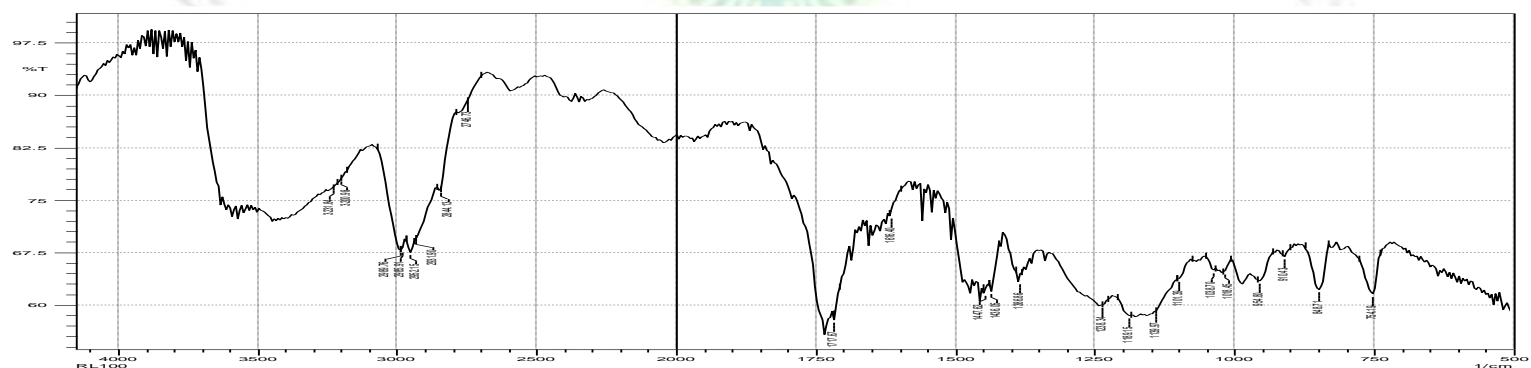

Figure 4: IR Spectrum of Eudragit RL100

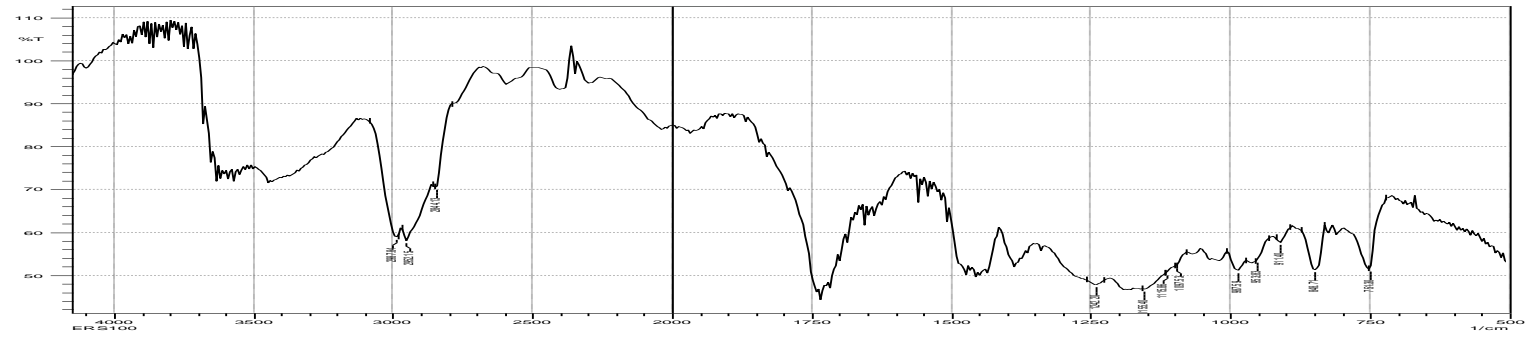

Figure 5: IR Spectrum of Eudragit RS100

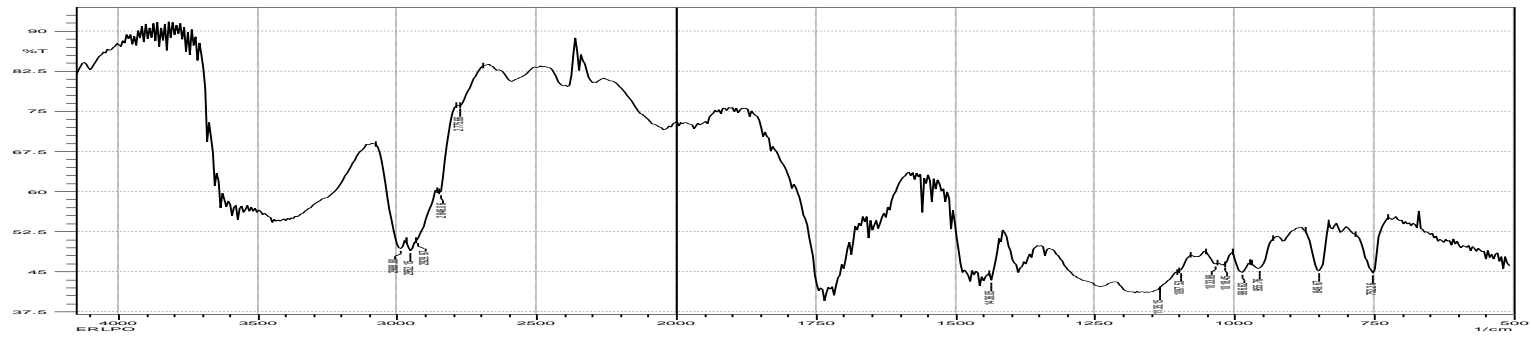

Figure 6: IR Spectrum of Eudragit RLPO 


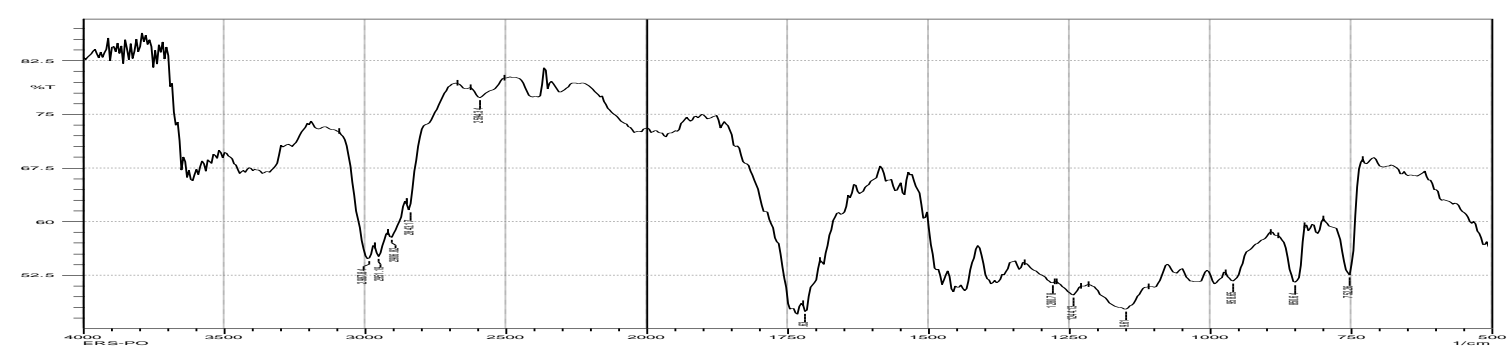

Figure 7: IR Spectrum of Eudragit RSPO

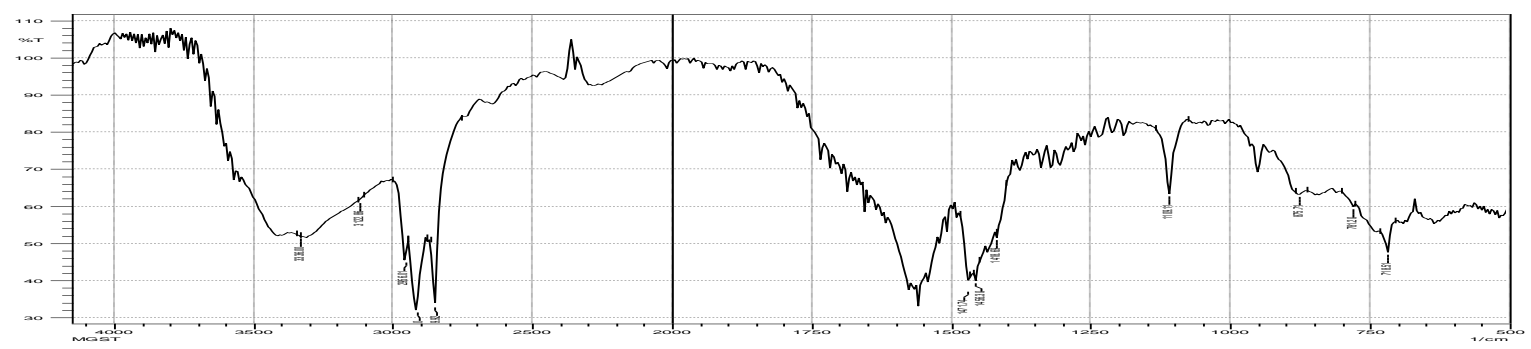

Figure 8: IR Spectrum of Magnesium Stearate

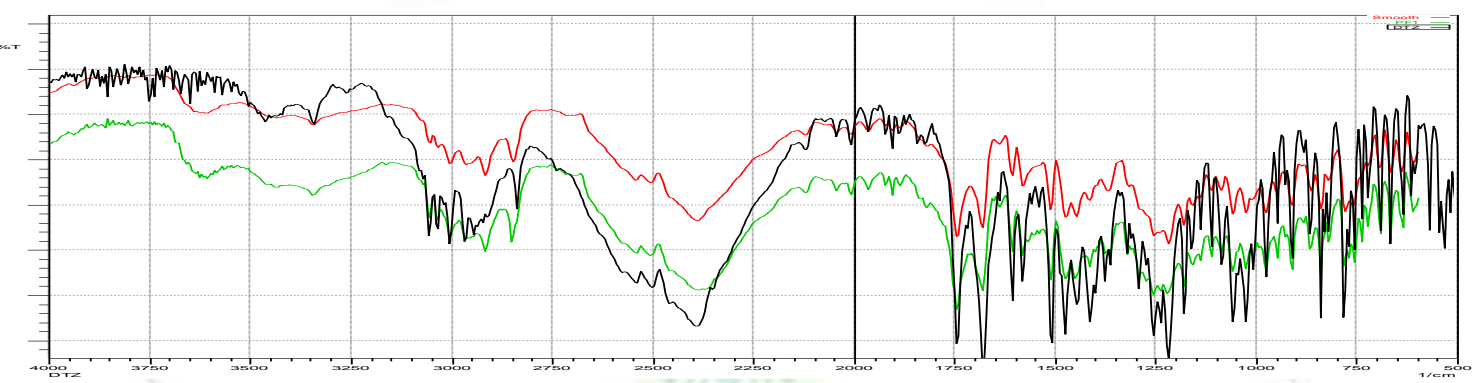

Figure 9: IR spectrum of DTZ.HCl, F1, PF1 (Physical mixture corresponding to F1)

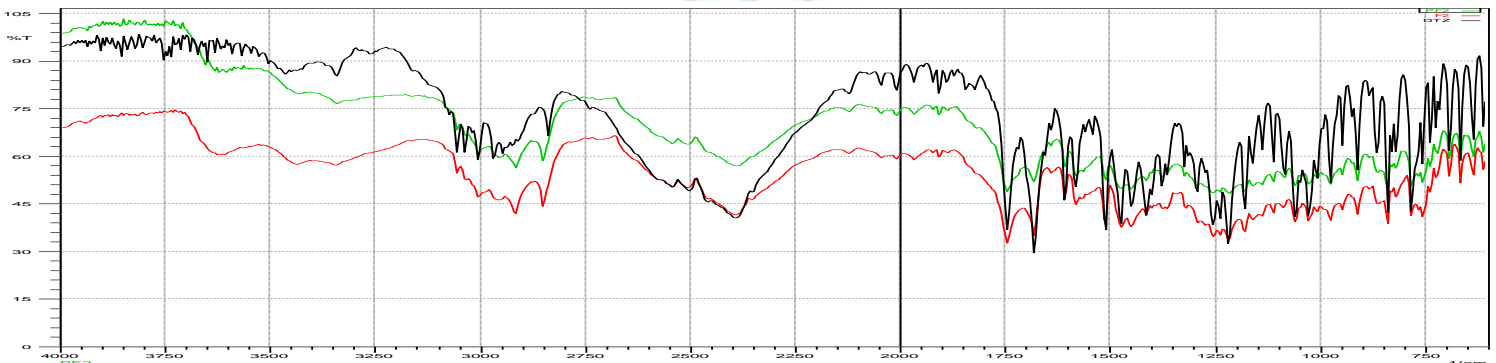

Figure 10: IR spectrum of DTZ.HCl, F2, PF2(Physical mixture corresponding to F2)

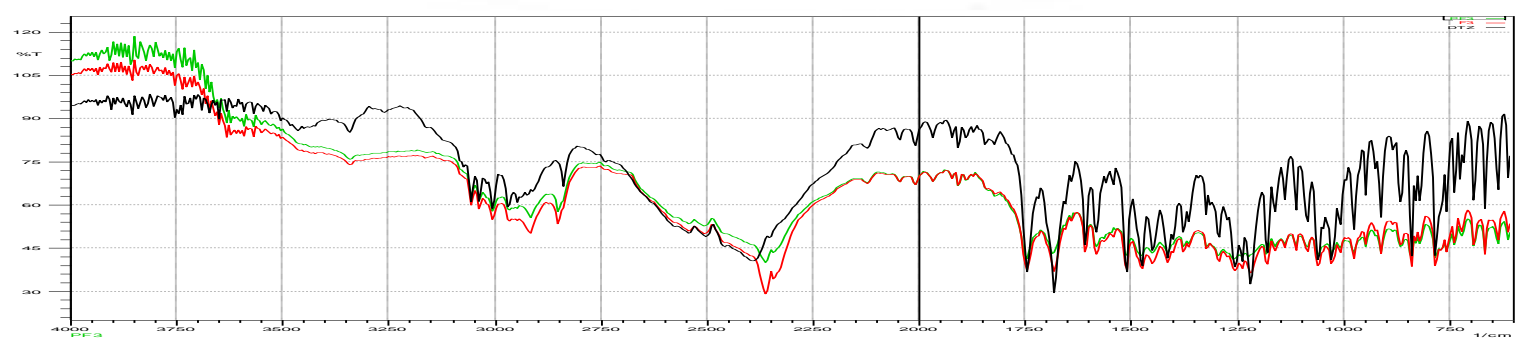

Figure 11: IR spectrum of DTZ.HCl, F3, PF3(Physical mixture corresponding to F3)

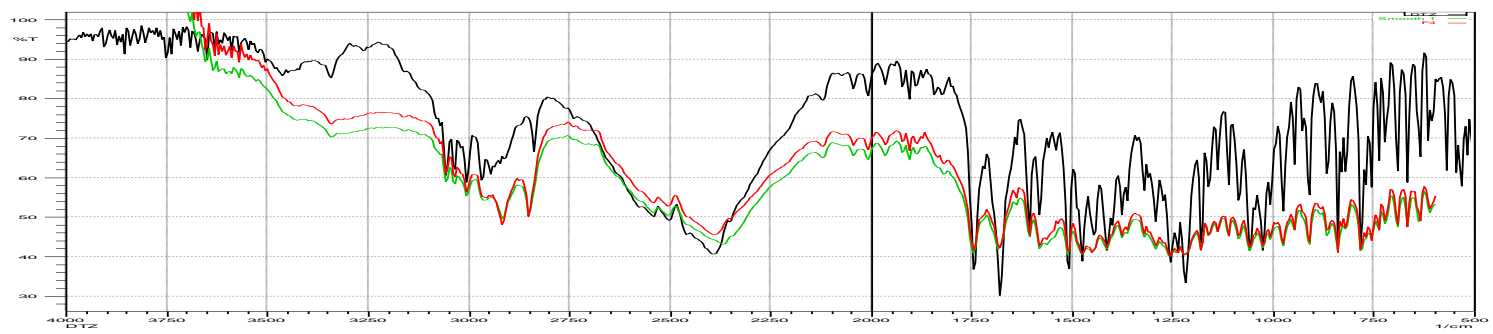

Figure 12: IR spectrum of DTZ.HCl, F4, PF4(Physical mixture corresponding to F4) 
Microspheres have received considerable attention in pharmaceutical and biomedical application, specifically achieving sustained release and controlled release objectives. Thus, it is an useful method for prolonging drug release from dosage forms, reducing adverse effects and to deliver drugs in a controlled manner. According to Biopharmaceutical Classification System (BCS), Diltiazem hydrochloride is having the characteristics of high solubility, high permeability. Thus it is covered under BCS class - I category. So, Diltiazem hydrochloride is a suitable candidate for sustain release formulation.

\section{Scanning and Standard plots of Diltiazem hydrochloride}

Scanning of Diltiazem hydrochloride was performed into Methanol, acid buffer ( $\mathrm{pH}$ 1.2) and phosphate buffer (pH 7.2). The characteristic peak, $\lambda_{\max }$ was found to be at 237,237 and $239 \mathrm{~nm}$ respectively.
Standard curve of Diltiazem hydrochloride was plotted in Methanol, acid buffer ( $\mathrm{pH}$ 1.2) and phosphate buffer $(\mathrm{pH}$ 7.2). The critical values for regression co-efficient in each plot were less than 0.001 (i.e., $\mathrm{P}<0.001$ ). That indicates that there was high linear correlation between concentrations of drug with absorbance.

\section{IR Spectroscopy (FTIR)}

This technique is used to determine any chemical interactions between drug and excipients. The Fourier transformed infrared (FTIR) spectra of drug, polymers, formulations and mixtures were obtained using FTIR Spectrophotometer (FTIR - 8400S (CE), SHIMADZU). The intermediate mixtures of drug with each polymer were prepared for each formulation of $\mathrm{F}_{1}, \mathrm{~F}_{2}, \mathrm{~F}_{3}$ and $\mathrm{F}_{4}$ as microspheres and subjected to analysis by FTIR. Spectra is shown in Fig and results were tabulated below-

Table 3: Wave- number of different functional groups present in Diltiazem.HCl

\begin{tabular}{|l|l|l|l|l|l|l|}
\hline \multirow{2}{*}{ Code } & \multirow{5}{*}{\begin{tabular}{l} 
Peak for Diltiazem hydrochloride \\
\cline { 3 - 7 }
\end{tabular}} & $\begin{array}{l}\text { Aromatic } \\
\text { C-H } \\
\text { Stretch }\left(\mathrm{cm}^{-1}\right)\end{array}$ & $\begin{array}{l}\text { O-CH } \\
\text { C-H stretch } \\
\left(\mathrm{cm}^{-1}\right)\end{array}$ & $\begin{array}{l}\text { Amine HCl } \\
\begin{array}{l}\text { N-H stretch } \\
\left(\mathrm{cm}^{-1}\right)\end{array}\end{array}$ & $\begin{array}{l}\text { Acetate } \\
\text { C=O stretch } \\
\left(\mathrm{cm}^{-1}\right)\end{array}$ & $\begin{array}{l}\text { Lactam } \\
\text { C=O stretch } \\
\left(\mathrm{cm}^{-1}\right)\end{array}$ \\
\hline DTZ.HCl & $\begin{array}{l}\text { Diltiazem } \\
\text { Hydrochloride }\end{array}$ & 3057.27 & 2837.38 & 2391.81 & 1743.71 & 1681.98 \\
\hline F1 & Formulation F1 & 3055.35 & 2847.03 & 2391.81 & 1743.71 & 1681.98 \\
PF1 & DTZ: ERL 100 & 3057.27 & 2839.31 & 2389.88 & 1745.64 & 1681.98 \\
\hline F2 & Formulation F2 & 3055.35 & 2850.88 & 2389.88 & 1743.71 & 1681.98 \\
PF2 & DTZ: ERS100 & 3057.27 & 285088 & 2389.88 & 1745.64 & 1681.98 \\
\hline F3 & Formulation F3 & 3057.27 & 2850.88 & 2360.95 & 1745.64 & 1681.98 \\
PF3 & DTZ: ERL PO & 3057.27 & 2839.31 & 2362.88 & 1745.64 & 1685.84 \\
\hline F4 & Formulation F4 & 3057.27 & 2850.88 & 2387.95 & 1745.64 & 1681.98 \\
Pf4 & DTZ: ERS PO & 3055.35 & 2850.88 & 2366.74 & 1745.64 & 1683.91 \\
\hline
\end{tabular}

Diltiazem hydrochloride is having $\mathrm{O}-\mathrm{CH}_{3}$, Amine, Acetate, Lactam as functional groups. These are the main sites where the chemical interaction may occur. After observing the spectra and above data, it could be concluded that the peak of these functional groups are intact in the intermediate mixtures and final formulations (Microspheres). As there was no shifting, deleting and broadening of the peak observed in the spectrum, it can be concluded that no chemical interactions had been occurred.

\section{REFERENCES}

1. Garg S, Sharma S, Gastroretentive drug delivery systems. Drug Deliv. Oral. 2003; 160-166.

2. Ansel HC, Allen L.V., Popouich N.G., Pharmaceutical Dosage Forms and Drug Delivery Systems, $7^{\text {th }}$ ed. Lippincott, Philadelphia, 2000; pp. 229-234.

3. Li H.K., Robinson J.R., Lee V.H.L., Influence of drug properties and routes of drug administration on the design of sustained and controlled release systems. In: Robinson, J.R., Lee, V.H.L. (Ed.), Controlled Drug Delivery Fundamentals and Applications, $2^{\text {nd }}$ ed. Marcel Dekker, New York, pp. 3-36.

4. Kilicarslan M., Baykara T., The effect of drug/polymer ratio on the properties of the Verapamil $\mathrm{HCl}$ loaded microspheres. Int. J. Pharm. 2003; 252:99-109.

5. Rastogi V, Shukla S, Singh R, Lal N, Yadav P. Microspheres: a promising drug carrier. Journal of Drug Delivery and Therapeutics, 2016; 6(3):18-26. doi:10.22270/jddt.v6i3.1196.

6. Kappor D, Patel M, Vyas R, Lad C, Tyagi B. A review on microsponge drug delivery system. Journal of Drug Delivery

and Therapeutics, 2014; 4(5):29-35. doi:10.22270/jddt.v4i5.978.

7. Indian Pharmacopoeia, 1996. Vol. I, Controller of Publications, Government of India, New Delhi, pp. 256-257.

8. Mazzo D.J., Obetz C.L., Shuster J., Diltiazem hydrochloride. In: Brittain, H.G. (Ed.), Analytical Profiles of Drug Substances and Excipients. Vol. 23, Academic Press, New York, 1994; pp. 53-98.

9. Martindale, The Complete Drug Reference, $33^{\text {rd }}$ ed. Martindale Pharmaceutical Press, London, pp. 857-859.

10. Dollery C., Therapeutic Drugs, Vol. I, $2^{\text {nd }}$ ed., Churchill Livingstone, UK, 1999; pp. D139-D143.

11. Tripathi K.D.,. Essentials of Medical Pharmacology, $5^{\text {th }}$ ed. Jaypee Brothers, New Delhi, 2004; pp. 486-498.

12. US Pharmacopoeia XXV, 2002. US Pharmacopoeial Convention Inc., Rockville, MD, pp. 581-584

13. Sood A., Panchagnula R., Drug release evaluation of diltiazem CR preparations. Int. J. Pharm. 1998; 175, 95-107. 